\title{
IMPLEMENTASI SUPERVISI MANAJERIAL PIMPINAN MENINGKATKAN KUALITAS GURU DI PESANTREN MODERN TA'DIB AL-SYAKIRIN MEDAN
}

\author{
Muhammad Iqbal \\ Program Studi Pendidikan Bahasa Arab STAI As-Sunnah Deli Serdang \\ Jl. Medan-Tg. Morawa, Km. 13, Gang Darmo, Desa Bangun Sari, Kecamatan Tanjung Morawa, \\ Kabupaten Deli Serdang, SUMUT
}

\begin{abstract}
Abstrak: Penelitian bertujuan untuk mengetahui: (1) Fungsi supervisi manajerial pimpinan dalam kaitannya dengan peningkatan kualitas guru di Pesantren Modern Ta'dib Al-Syakirin Medan, (2) Proses Tahapan yang dilakukan pimpinan dalam mengimplementasikan fungsi supervisi manajerial di Pesantren Modern Ta'dib Al-Syakirin Medan, (3) Kualitas Guru di sekolah Pesantren Modern Ta'dib Al-Syakirin Medan.Metode yang digunakan dalam penelitian ini adalah metode kualitatif, pengumpulan data penelitian dilakukan dengan memanfaatkan observasi, wawancara, dan pengkajian dokumen. Adapun langkah yang ditempuh dalam menganalisis data adalah dengan cara menyusun data, menghubungkan data, mereduksi, menyajikan data, kemudian disimpulkan. Sedangkan dalam mengkaji kevalidan atau tingkat kepercayaan data yang disajikan berikutnya dilakukan uji tingkat kepercayaan, keteralihan, kebergantungan, dan kepastian.Hasil temuan penelitian ini mengungkapkan empat temuan yaitu: (1) Fungsi supervisi manajerial pimpinan dalam kaitannya dengan peningkatan kualitas guru belum adanya keterbukaan dan transparansi serta kerjasama yang baik antara pimpinan dengan seluruh guru,(2) Proses Tahapan yang dilakukan pimpinan dalam mengimplementasikan fungsi supervisi manajerial bahwa sistem demokratis dan delegasi merupakan suatu sistem yang dilakukan pimpinan belum menunjukkan secara kapasitasnya, (3) Kualitas Guru di Pesantren Modern Ta'dib Al-Syakirin Medan belum memenuhi kompetensi kualitas serta standar untuk menjadi acuan sebagai guru yang berkualitas.
\end{abstract}

Kata Kunci: Supervisi Manajerial, Pimpinan Pesantren, Guru dan Pesantren

\section{PENDAHULUAN}

Pemimpin berperan sangat penting dalam menyukseskan dan memperoleh tujuan akhir yang telah ditentukan bersama. Untuk itu, seorang pemimpin harus mempunyai tanggung jawab yang tinggi. Dengan begitu, pemimpin yang baik adalah pemimpin yang dapat menjalankan tugasnya dengan baik pula terutama dalam bidang pengawasan. Hal ini melihat seberapa efektif dan efisien suatu pekerjaan atau kegiatan yang telah dilakukan seseorang.

Tugas manajer atau pimpinan lembaga pendidikan yang berhubungan secara langsung dengan fungsi-fungsi manajemen lainnya, yaitu fungsi pengawasan, pembinaan dan pengarahan. Fungsi pembinaan dilaksanakan oleh 
pimpinan ke setiap unit kerja untuk menilai tingkat perkembangan dan kemajuan kinerja pegawai serta pelaksanaan berbagai kegiatan lembaga pendidikan. Tugas tersebut merupakan salah satu fungsi manajemen.

Secara subtansial, fungsi dari pengawasan dan pembinaan adalah membentuk kesadaran, kemauan, dan kesediaan kerja yang disempurnakan oleh sikap ketaatan atau tunduk terhadap semua peraturan dan norma yang berlaku. Setiap kesadaran kerja adalah sikap sukarela yang merupakan panggilan nurani. Dengan demikian, keikhlasan bekerja bermakna pengabdian yang tulus terhadap tugas dan kedudukan seseorang dalam bekerja.(Hikmat, 2009)

Dari observasi awal penelitian yang dilakukan, menemukan data bahwa di Pesantren Modern Ta'dib Al-Syakirin Medan belum ada perencanaan yang sistematis guna memperjelas sasaran utama dan strategi yang seharusnya dilakukan pihak pesantren untuk meningkatkan kualitas tenaga pendidik di pesantrennya guna perwujudan pendidikan yang efektif dalam penyelenggaraan proses pendidikan, contohnya belum adanya perencanaan strategik dalam peningkatan mutu guru, belum adnya perencanaan strategik dalam peningkatan mutu pembelajaran, perencanaan strategik dalam peningkatan mutu kesiswaan, dan perencanaan strategik dalam peningkatan mutu sarana dan prasarana. Pimpinan dalam hal ini menempati kedudukan strategis diantara orang-orang yang berada dalam organisasi pesantren yang mampu melaksanakan perencanaan strategik untuk mengelola pelaksanaan mutu pendidikan agar berjalan efektif.

Dari gambaran di atas, pengawasan pesantren yang merupakan bagian terpenting dalam lembaga pendidikan yang mengarah kepada perbaikan kualitas tenaga pendidik agar tercapai tujuan pendidikan yang diharapkan, maka peneliti merasa tertarik untuk mengadakan penelitian tentang "Implementasi Supervisi Manajerial Pimpinan dalam Meningkatkan Kualitas Guru di Pesantren Modern Ta'dib Al-Syakirin Medan”.

Penelitian ini bertujuan untuk mengetahui bagaimana Pimpinan pesantren menerapkan fungsi supervisi manajerial dan bagaimana proses tahapan dalam menerapkan fungsi supervisi manajerial di Pesantren Modern Ta'dib Al-Syakirin Medan agar dapat meningkatkan kualitas tenaga pendidik disekolah tersebut. Maka dapat disimpulkan bahwa pendekatan yang digunakan adalah pendekatan 
kualitatif deskriptif yaitu "Penelitian yang dilakukan berusaha untuk memaparkan suatu keadaan, gejala individu atau kelompok tertentu secara analisis yang dalam mengolah dan menganalisis datanya tidak tertumpu pada penggunaan angkaangka statistik, kecuali sebagai alat bantu.(Ismail, 1993, p. 3)

Penelitian ini dilakukan di Pesantren Modern Ta'dib Al-Syakirin Jalan. Brigjend Zein Hamid Km. 7,5 Gg. Tapian Nauli Titi Kuning Medan Johor. Hal ini peneliti melakukan observasi/penelitian dalam kurun waktu lebih kurang 2 bulan dan pengambilan data untuk bahan perlengkapan penelitian. Objek penelitian ini adalah mengenai Implementasi Supervisi Manajerial Pimpinan dalam Meningkatkan Kualitas Guru di Pesantren Modern Ta'dib Al-Syakirin Medan. Sedangkan sebagai subjeknya adalah Pimpinan pesantren, direktur pesantren, Tenaga Pendidik dan Kependidikan serta guru di Pesantren Modern Ta'dib AlSyakirin Medan.

Teknik yang saya gunakan dalam penelitian ini adalah dengan teknik utama yaitu observasi, setalah itu digunakan teknik wawancara dan sebagai pendukung digunakan teknik dukumentasi. Analisis data dalam penelitian dengan menggunakan dengan menggunakan pendekatan kualitatif dilakukan secara berkesinambungan dari awal sampai akhir proses penelitian. Adapun proses analisis data yaitu reduksi data, penyajian data dan penarikan kesimpulan. Untuk menghindari kesalahan data yang akan dianalisis, peneliti menggunakan keabsahan data dengan kredibilitas, keteralihan, ketergantungan dan kepastian.

\section{Pembahasan}

\section{A. Supervisi Pendidikan}

\section{Pengertian Supervisi Pendidikan}

Dalam membicarakan supervisi pendidikan, tentu harus merujuk pada definisi ahli, sehingga apa yang dipahami terkait dengan supervisi pendidikan akan sesuai dengan yang diharapkan. Secara etimologi istilah supervisi diambil dalam bahasa inggris "supervision" artinya pengawasan dibidang pendidikan. Orang yang melakukan supervisi disebut supervisor.(Muhammad Rahman, 2014)

Supervisi meskipun mengandung arti atau sering diterjemahkan sebagai pengawasan, namun mempunyai arti khusus yaitu "membantu" dan turut serta dalam usaha-usaha perbaikan dan meningkatkan mutu. Supervisi, mempunyai 
fungsi penilaian (evaluation) dengan jalan penelitian (research) dan merupakan usaha perbaikan (improvement).(M. Ardiansyah, 2017, pp. 121-124)

Secara umum kenapa supervisi pendidikan diperlukan karena dilatar belakangi oleh berkembangnya science dan teknologi, adanya tuntutan hak asasi manusia, petumbuhan ekonomi dan kemakmuran yang tidak merata, suburnya birokrasi dan system yang bertingkat, membantu dan membina guru-guru yang kurang bermutu, pertumbuhan jabatan, peraturan dan tuntutan Negara, kultural, filosofis, psikologis dan sosiologis.

Dari beberapa pendapat di atas, dapat ditarik kesimpulan bahwa pada hakikatnya supervisi pendidikan dapat diartikan sebagai bimbingan professional bagi guru-guru. Bimbingan professional yang dimaksdukan adalah segala usaha yang memberikan kesempatan bagi guru-guru untuk berkembang secara profesioanal, sehingga mereka lebih maju lagi dalam melaksanakan tugas pokoknya yaitu memperbaiki dan meningkatkan proses belajar mengajar.

\section{Tujuan Supervisi Pendidikan}

Tujuan supervisi itu sendiri adalah memberikan layanan dan bantuan untuk mengembangkan situasi belajar mengajar yang dilakukan guru di kelas, untuk mengembangkan kemampuan mengajar dan potensi kualitas guru.

Tujuan supervisi secara umum adalah mengembangkan situasi belajar mengajar yang lebih baik melalui pembinaan dan peningkatan profesi mengajar. Dan supervisi juga bertujuan untuk menghimpun informasi atau kondisi nyata pelaksanaan tugas pendidik dan tenaga kependidikan sesuai dengan tujuan pokoknya sebagai dasar untuk melakukan pembinaan dan tindak lanjut perbaikan kinerja belajar siswa. Selanjutnya adalah bermanfaatnya akreditasi untuk melakukan perbaikan mutu.

Sebagai seorang supervisor, pimpinan mempunyai tugas-tugas pokok yang harus dilaksanakan. Dia harus mampu menganalisa, mengobservasi semua hal yang dapat membantu dalam pengembangan pesantren, mengorganisir seluruh staff dalam peningkatan kinerja dan kompetensi dirinya, menjalin hubungan mitra dengan luar pesantren yang dapat menunjang pada kepentingan pesantren.

\section{Fungsi Supervisi Pendidikan}


Diadakannya sebuah pengawasan atau supervisi oleh pimpinan pesantren atau atasan adalah sebuah tindakan yang semestinya yang harus dilakukan untuk mengawasi timbulnya situasi-situasi yang menghambat jalannya administrasi pendidikan di pesantren. Karena hambatan itu semakin lama semakin banyak maka ada kemungkinan tujuan tidak tercapai dalam waktu yang telah direncanakan. Karena situasi yang menghambat itu dapat berasal dari berbagai pihak.

Secara singkat dapat disimpulkan, bahwa fungsi atau tugas supervisi pendidikan adalah menjalankan aktivitas untuk mengetahui situasi pendidikan di pesantren serta menjalankan aktivitas untuk mempertinggi hasil dan untuk menghilangkan hambatan-hambatan.

\section{Teknik Supervisi Pendidikan}

Beberapa teknik supervisi yang dapat digunakan supervisor pendidikan menurut (Indonesia, 2011, pp. 316-318) antara lain:

a. Kunjungan kelas secara berencana untuk memperoleh gambaran tentang kegiatan belajar mengajar di kelas

b. Pertemuan pribadi antara supervisor dengan guru untuk membicarakan masalah-masalah khusus yang dihadapi guru

c. Rapat antara supervisor dengan para guru di pesantren, biasanya untuk membicarakan masalah-masalah umum yang menyangkut perbaikan atau peningkatan mutu pendidikan

d. Kunjungan antar kelas atau antar pesantren merupakan suatu kegiatan yang terutama untuk saling menukarkan pengalaman sesama guru atau pesantren tentang usaha-usaha perbaikan dalam proses belajar-mengajar.

e. Pertemuan-pertemuan dikelompok kerja penilik, kelompok kerja pesantren, serta pertemuan kelompok kerja guru, pusat kegiatan guru dan sebagainya. Pertemuan-pertemuan tersebut dapat dilakukan oleh masingmasing kelompok kerja atau gabungan yang terutama dimaksudkan untuk menemukan masalah, mencari alternative penyelesaian serta menerapkan alternative masalah yang tepat.

\section{A. Supervisi Manajerial Pimpinan Pesantren}

\section{Supervisi Manajerial}


Supervisi manajerial merupakan supervisi yang ditujukan pada bidang manajemen pesantren. Tujuannya ialah agar pimpinan pesantren mampu mengelola pendidikan sesuai dengan standar mutu yang telah ditetapkan. Di dalamnya terdapat upaya pemantauan dan pembinaan manajemen pesantren.

\section{Fungsi Supervisi Manajerial}

Supervisi manajerial atau pengawasan majerial merupakan fungsi supervisi yang berkenaan dengan aspek pengelolaan pesantren yang terkait langsung dengan peningkatan efisiensi dan efektivitas pesantren yang mencakup perencanaan, koordinasi, pelaksanaan, penilaian, pengembangan kompetensi sumber daya tenaga pendidik, dan kependidikan. Sasaran supervisi manjerial adalah membantu pimpinan pesantren dan staf pesantren lainnya dalam mengelola administrasi pendidikan, seperti a) administrasi kurikulum; b) administrasi keuangan; c) administrasi sarana prasarana/perlengakapan; d) administrasi personal atau ketenagaan; e) administrasi kesiswaan; f) administrasi hubungan sekolah dan masyarakat; g) administrasi budaya dan lingkungan pesantren dan h) aspek-aspek administrasi lainnya dalam upaya meningkatkan mutu pendidikan.

\section{Konsep Dasar Pimpinan}

Dalam bahasa Indonesia "pemimpin" sering disebut penghulu, pemuka, pelopor, pembina, panutan, pembimbing, pengurus, penggerak, ketua, kepala, penuntun, raja, tua-tua, dan sebagainya. Sedangkan istilah Memimpin digunakan dalam konteks hasil penggunaan peran seseorang berkaitan dengan kemampuannya mempengaruhi orang lain dengan berbagai cara.

Istilah pemimpin, kemimpinan, dan memimpin pada mulanya berasal dari kata dasar yangsama "pimpin". Namun demikian ketiganya digunakan dalam konteks yang berbeda.

Pemimpin adalah suatu lakon/peran dalam sistem tertentu; karenanya seseorang dalam peran formal belum tentu memiliki ketrampilan kepemimpinan dan belum tentu mampu memimpin. Istilah Kepemimpinan pada dasarnya berhubungan dengan ketrampilan, kecakapan, dan tingkat pengaruh yang dimiliki seseorang; oleh sebab itu kepemimpinan bisa dimiliki oleh orang yang bukan "pemimpin". 


\section{Pimpinan Sebagai Supervisor}

Pimpinan sebagai supervisor artinya pimpinan berfungsi sebagai pengawas, pengendali, pembina, pengarah, dan pemberi contoh kepada guru dan pegawai di pesantren. Salah satu hal yang terpenting bagi pimpinan, sebagai supervisor adalah memahami tugas dan kedudukan pegawai di pesantren yang dipimpinnya.

Dengan demikian, pimpinan bukan hanya mengawasi pegawai dan guru yang sedang melaksanakan kegiatan, tetapi ia membekali diri dengan pengetahuan dan pemahaman tentang tugas dan fungsi stafnya, agar pengawasan dan pembinaan berjalan dengan baik dan tidak membingungkan.

\section{Pesantren}

Istilah pesantren berasal dari kata pe-santri-an, di mana kata "santri" berarti murid dalam Bahasa Jawa. Istilah pondok berasal dari Bahasa Arabfunduuq (فندوق) yang berarti penginapan. Khusus di Aceh, pesantren disebut juga dengan nama dayah. Biasanya pesantren dipimpin oleh seorang Kyai. Untuk mengatur kehidupan pondok pesantren, kyai menunjuk seorang santri senior untuk mengatur adik-adik kelasnya, mereka biasanya disebut lurah pondok. Tujuan para santri dipisahkan dari orang tua dan keluarga mereka adalah agar mereka belajar hidup mandiri dan sekaligus dapat meningkatkan hubungan dengan kyai dan juga Tuhan.

Pendapat lainnya, pesantren berasal dari kata santri yang dapat diartikan tempat santri. Kata santri berasal dari kata Cantrik (bahasa Sansakerta, atau mungkin Jawa) yang berarti orang yang selalu mengikuti guru, yang kemudian dikembangkan oleh Perguruan Taman Siswa dalam sistem asrama yang disebut Pawiyatan. Istilah santri juga dalam ada dalam bahasa Tamil, yang berarti guru mengaji, sedang C. Berg berpendapat bahwa istilah tersebut berasal dari istilah shastri, yang dalam bahasa India berarti orang yang tahu buku-buku suci agama Hindu atau seorang sarjana ahli kitab suci agama Hindu. Terkadang juga dianggap sebagai gabungan kata saint (manusiabaik) dengan suku kata tra (suka menolong), sehingga kata pesantren dapat berarti tempat pendidikan manusia baik-baik(Fatah, 2005, p. 11). 


\section{B. Guru}

\section{Pengertian Guru}

Menurut Undang-Undang Nomor 14 Tahun 2005 pasal 1 ayat 1 tentang guru dan dosen: guru adalah pendidik professional dengan tugas utama mendidik, mengajar, membimbing, mengarahkan, melatih, menilai dan mengevaluasi peserta didik pada pendidikan anak usia dini jalaur pendidikan formal, pendidikan dasar, dan pendidikan menengah.

Secara umum istilah pendidikan dikenal dengan guru. Hadari Nawawi, mengatakan bahwa guru adalah orang yang kerjanya mengajar atau memberikan pelajaran disekolah/ kelas. Secara khusus Hadari Nawawi mengatakan bahwa guru adalah orang yang ikut bertanggungjawab dalam membantu anak mencapai kedewasaan masing-masing. Guru bukanlah sekedar orang yang berdiri didepan kelas menyampaikan materi pengetahuan tertentu, akan tetapi adalah anggota masyarakat yang harus ikut aktif dan berjiwa besar serta kreatif dalam mengarahkan perkembangan anak didiknya untuk menjadi anggota masyarakaat sebagai orang dewasa(Rahmat Hidayat, 2016, pp. 115-127)

Guru sebagai tenaga pendidik yang dipandang memiliki keahlian tertentu dalam pendidikan dan pembelajaran, diserahi tugas dan wewenang untuk mengelola kegiatan pembelajaran agar dapat mencapai tujuan tertentu yaitu terjadinya perubahan tingkah laku siswa dengan tujuan pendidikan nasional dan tujuan institusional yang telah dirumuskan.

\section{Peranan dan Kedudukan Guru}

Peranan guru disekolah ditentukan oleh kedudukannya sebagai orang dewasa, sebagai pengajar dan pendidik dan sebagai pegawai. Yang utama ialah kedudukannya sebagai pengajar dan pendidik, yakni sebagai guru. Berdasarkan kedudukannya sebagai guru ia harus menunjukkan kelakuan yang layak bagi guru menurut harapan masyarakat. Apa yang dituntut dari guru dalam aspek etis, inteltual dan social lebih tinggi daripada yang dituntut dari orang dewasa lainnya

Pendidik hendaknya memiliki karakteristik yang dapat membedakan darinya dengan orang lain. Dengan karakteristik yang dimiliki pendidik, maka hal itu akan menjadi ciri khas dan sifat yang menyatu dalam seluruh totalitas 
kepribadiannya. Totalitas tersebut kemudian akan teraktualisasi melalui seluruh perkataan dan perbuatan yang dilakukannya.

\section{Fungsi Guru}

Pendidik sebagai seorang yang terdepan dalam pendidikan, secara umum memiliki fungsi sebagai berikut:

a. Sebagai pengajar (instruksional), yang bertugas merencanakan program pengajaran dan melaksanakan program yang telah disusun serta mengakhiri dengan melaksanakan penilaian setelah program dilaksanakan.

b. Sebagai pendidik (educator), yang mengarahkan peserta didik pada tingkat kedewasaan dan berkepribadian kamil sering dengan tujuan Allah Swt yang meniptakannya (makhluk).

c. Sebagai pemimpin (manajerial), yang memimpin, mengendalikan kepada diri sendiri, peserta didik dan masyarakat yang terkait, terhadap berbagai masalah yang menyangkut upaya pengarahan, pengawasan, pengorganisasian, pengontrolan, dan partisipasi atas program pendidikan yang dilakukan(Rahmat Hidayat, 2016, pp. 125-127).

\section{Karakteristik Guru Ideal}

Untuk menjadi orang yang pantas ditaati dan diikuti, tidaklah salah apabila sebagai guru melihat kembali apa yang telah diungkapkan al-Zarnuji bahwa " $W a$ amma ikhtiyaru al-ustadzi fayambaghi an yakhtara al-'alam wa al-aura'a wa alasanna kama ikhtara Abu Hanifah hinaidzin Hamad bin Abi Sulaiman ba'da alta'ammuli wa al-tafakkuri. "Sebaiknya dalam memilih guru, pilihlah orang yang lebih alim, wara' dan lebih tua usianya, sebagaimana Abu Hanifah di masa belajarnya memilih Syaekh Hamad bin Abi Sulaiman sebagai gurunya setelah beliau benar-benar merenung dan berfikir.

\section{TEMUAN DAN PEMBAHASAN}

\section{Fungsi Supervisi Manajerial Pimpinan Dalam kaitannya dengan Peningkatan Kualitas Guru}

Dari seluruh hasil wawancara peneliti simpulkan bahwasanya fungsi supervisi manajerial pimpinan pesantren dalam kaitannya dengan peningkatan kualitas guru ini ialah belum adanya keterbukaan dan transparansi serta kerjasama yang baik 
antara pimpinan pesantren dengan seluruh guru dalam hal meningkatkan kualitas guru mulai dari perencanaan dengan melihat kemampuan dan kebutuhan lembaga serta memperhatikan hal yaitu; belum membuat perkiraan ke depan dengan baik, belum adanya penetapan tujuan, belum adanya penentuan prioritas, belum adanya penetapan jadwal dan belum adanya penetapan biaya.

Kemudian dalam hal menentukan dan menempatkan masing-masing guru dan kependidikan pada wewenang dan tanggung jawabnya sesuai dengan harapan dan sasaran yang diharapkan untuk dapat dilaksanakan dengan memperhatikan pembagian kelompok kerja, menentukan tugas masing-masing, pemberian wewenang dan menetapkan jalinan kerjasama tim serta pengawasan yang efektif dengan kepemimpinan yang demokrasi kepada seluruh guru.

Berkenaan dengan hal itu, Supervisi manajerial merupakan supervisi yang ditujukan pada bidang manajemen pesantren. Tujuannya ialah agar pimpinan pesantren mampu mengelola pendidikan sesuai dengan standar mutu yang telah ditetapkan. Di dalamnya terdapat upaya pemantauan dan pembinaan manajemen pesantren.

Supervisi manajerial atau pengawasan majerial merupakan fungsi supervisi yang berkenaan dengan aspek pengelolaan pesantren yang terkait langsung dengan peningkatan efisiensi dan efektivitas pesantren yang mencakup perencanaan, koordinasi, pelaksanaan, penilaian, pengembangan kompetensi sumber daya guru, dan kependidikan.

\section{Proses Tahapan Yang Dilakukan Kepala Sekolah Dalam Mengimplementasikan Fungsi Supervisi Manajerial}

Dari keterangan hasil wawancara disimpulkan bahwa dapat memberikan gambaran kepada peneliti bahwanyasistem demokratis dan delegasi merupakan suatu sistem yang dilakukan Pimpinan PesantrenModern Ta'dib Al-Syakirin Medan belum menunjukkan secara kapasitasnya. Sistem demokrasi adalah komunikasi yang terbuka untuk semua pihak kepada seluruh jajaran yang ada di bawahnya. Sifat ini merupakan suatu bentuk komunikasi yang ideal, dimana beliau belum mengedepankan sikap bersama dan terbuka. Rasanya sikap seperti ini memang harus dikembangkan mengingat beliau adalah seorang pemimpin yang mana setiap saat dibutuhkan para bawahannya. Maka apabila sikap ini tidak 
dimiliki maka keegoisan akan mengikuti setiap permasalahan yang ada. Dan ini tentunya tidak diharapkan semua pihak, karena akibatnya bisa memberikan dampak negatif yang berimbas kepada sulitnya untuk mencapai tujuan yang telah ditentukan.

Selain demokrasi beliau juga menggunakan sistem delegasi yaitu perpanjangan tangan dari beliau terhadap penyelesaian masalah-masalah yang tidak bisa ditanganinya secara langsung. Menurut penjelasan di atas bahwa tugas dan tanggungjawab yang telah diberikan kepada delegasinya tersebut tidak terlepas dari pantauan dan pengamatan beliau. Dan sistem ini juga bukan sebagai bentuk kemalasan dari Pimpinan pesantren, tetapi harus kita ketahui bahwa tidak semua permasalahan mesti ditangani oleh Pimpinan pesantren, tetapi harus ada bidang-bidang tertentu yang lebih fokus mengurus masalah tersebut. Sehingga problem dan tugas yang dijalankan bisa lebih terarah kejalur yang telah ditentukan.

Berbagai teknik atau cara yang dapat digunakan pimpinan pesantren dalam membantu guru meningkatkan situasi belajar mengajar, baik secara kelompok (group techniques), maupun secara perorangan (individual techniques) ataupun dengan cara langsung atau bertatap muka dan cara tak langsung atau melalui media komunikasi (visual, audial, audio visual).

\section{Kualitas Guru}

Kualitas tenaga pendidik di sekolah Madrasah Tsanawiyah Negeri Tanah Jawa belum memenuhi kompetensi kualitas serta standar untuk menjadi acuan sebagai tenaga pendidik yang berkualitas baik itu hasil yang didapat dari kepala madrasah, wakil kepala madrasah dan juga peserta didik.

Sebagaimana seharusnya, bahwa untuk menjadi guru atau tenaga pendidik yang berkompetensi secara professional haruslah memiliki karakteristik.

Gary dan Margaret dalam Mulyasa memaparkan bahwa guru yang efektif dan kompetensi secara professional memiliki karakteristik sebagai berikut:

a. Memiliki kemampuan menciptakan iklim belajar yangkondusif, berkaitan dengan:

1) Kemampuan interpersonal untuk menunjukkan empati dan penghargaan kepada peserta didik 
2) Hubungan baik dengan peserta didik

3) Menerima dan memperhatikan pesrta didik dengan tulus

4) Menunjukkan minat dan antusias yang tinggi dalam mengajar

5) Menciptakan iklim untuk tumbuhnya kerjasama

6) Melibatkan peserta didik dalam mengorganisasikan dan merencanakan pembelajaran, mendengarkan dan menghargai hal peserta didik untuk berbicara dalam setiap diskusi.

7) Meminimalkan bahkan mngeleminasi setiap permasalahan yang sering terjadi dalam pembelajaran

b. Memiliki kemampuan mengembangkan strategi dan manajemen pembelajaran, berkaitan dengan:

1) Kemampuan untuk menghadapi dan menangani peserta didik yang bermasalah, suka menyela, mengalihkan pembicaraan.

2) Mampu memberikan transisi substansi bahan ajar dalam pembelajaran

3) Kemampuan bertanya yang memerlukan tingkat berfikir yang berbeda untuk semua peserta didik

c. Memiliki kemampuan memberikan umpan balik (feedback) dan penguatan (reinforcement), berkaitan dengan:

1) Memberikan umpan balik yang positif terhadap respon peserta didik

2) Memberikan respon yang sifatnya membantu terhadap peserta didik yang lambat belajar

3) Memberikan tindak lanjut terhadap jawaban peserta didik yang kurang memuaskan

4) Kemampuan memberikan bantuan professional kepada peserta didik jika diperlukan

d. Memiliki kemampuan untuk peningkatan diri, berkaitan dengan:

1) Menerapkan kurikulum dan metode mengajar secara inovatif

2) Memperluas dan menambah pengetahuan tentang metode pembelajaran

3) Memanfaatkan kelompok kerja guru (KKG) untuk menciptakan dan mengembangkan metode peembelajaran yang relevan.

\section{KESIMPULAN DAN SARAN}




\section{Kesimpulan}

Berdasarkan pembahasan dan uraian-uraian di atas, maka penulis dapat mengambil kesimpulan ke dalam beberapa poin berikut ini:

Fungsi Supervisi manajerial pimpinan pesantren dalam kaitannya dengan peningkatan kualitas guru di Pesantren Modern Ta'dib Al-Syakirin Medan yang dilakukan oleh Pimpinan pesantren kepada para guru yang mengajar di pesantren tersebut bahwasanya fungsi supervisi manajerial pimpinan pesantren dalam kaitannya dengan peningkatan kualitas guru ini ialah belum adanya keterbukaan dan transparansi serta kerjasama yang baik antara pimpinan pesantren dengan seluruh guru dalam hal meningkatkan kualitas guru mulai dari perencanaan dengan melihat kemampuan dan kebutuhan lembaga serta memperhatikan hal yaitu; belum membuat perkiraan ke depan dengan baik, belum adanya penetapan tujuan, belum adanya penentuan prioritas, belum adanya penetapan jadwal dan belum adanya penetapan biaya.

Kemudian dalam hal menentukan dan menempatkan masing-masing guru dan kependidikan pada wewenang dan tanggung jawabnya sesuai dengan harapan dan sasaran yang diharapkan untuk dapat dilaksanakan dengan memperhatikan pembagian kelompok kerja, menentukan tugas masing-masing, pemberian wewenang dan menetapkan jalinan kerjasama tim serta pengawasan yang efektif dengan kepemimpinan yang demokrasi kepada seluruh guru.

Proses tahapan yang dilakukan pimpinan pesantren dalam mengimplementasikan fungsi supervisi manajerial di Pesantren Modern Ta'dib Al-Syakirin Medan adalah dengan sistem demokratis dan delegasi merupakan suatu sistem yang dilakukan Pimpinan pesantren belum maksimal. Sistem demokrasi adalah komunikasi yang terbuka untuk semua pihak kepada seluruh jajaran yang ada di bawahnya. Sifat ini merupakan suatu bentuk komunikasi yang ideal, dimana beliau belum mengedepankan sikap bersama dan terbuka. Rasanya sikap seperti ini memang harus dikembangkan mengingat beliau adalah seorang pemimpin yang mana setiap saat dibutuhkan para bawahannya. Maka apabila sikap ini tidak dimiliki maka keegoisan akan mengikuti setiap permasalahan yang ada. Dan ini tentunya tidak diharapkan semua pihak, karena 
akibatnya bisa memberikan dampak negatif yang berimbas kepada sulitnya untuk mencapai tujuan yang telah ditentukan.

Kualitas Guru di Pesantren Modern Ta'dib Al-Syakirin Medan bahwasannya belum memenuhi kompetensi kualitas serta standar untuk menjadi acuan sebagai guru yang berkualitas baik itu hasil yang didapat dari pimpinan pesantren, direktur pesantren dan juga peserta didik.

Pimpinan pesantren di sarankan agar dapat lebih meningkatkan lagi Supervisi manajerial di Pesantren Modern Ta'dib Al-Syakirin Medan dalam hal ini untuk memotivasi guru-guru agar proses belajar mengajar dapat ditingkatkan dari tahun ketahun

Disarankan kepada para anggota dewan guru yang bertugas di Pesantren Modern Ta'dib Al-Syakirin Medan agar bekerja sama dengan Pimpinan pesantren untuk meningkatkan supervisi manajerial dalam rangka mewujudkan proses belajar-mengajar.

Penulis sarankan juga kepada siswa-siswi yang belajar di Pesantren Modern Ta'dib Al-Syakirin Medan agar lebih giat lagi untuk belajar dalam rangka mempersiapkan ilmu dan iman untuk masa depan. 


\section{Pustaka Acuan}

Abdul Mujib dan Yusuf Mudzakkir. Ilmu Pendidikan Islam. Jakarta: Prenada, 2010.

Ahmad Rohani dan Abu Ahmad. Pengembangan Pengajaran. Jakarta: Rineka Cipta, 1991.

Ahmad Tafsir. Ilmu Pendidikan dalam Perspektif Islam. Bandung: Rosdakarya, 2004.

Al Imam Al Hafidz. Tafsir Ibnu Katsir

Andri Feriyanto dan Endang Shtya Triana. PengantarManajemen (3 in 1) untuk Mahasiswa dan Umum. Yogyakarta: Mediata, 2015.

As-Suwaidan dan Basyarahil. Memproduksi Pemimpin Hebat. Surabaya: Pustaka Yassir, 2009.

Barnawi \& Mohammad Arifin. Meningkatkan Kinerja Pengawas Sekolah: Upaya Upgrade Kapasitas Kerja Pengawas Sekolah.Yogyakarta: Ar-Ruzz Media, 2014.

Eka Prihatin.Teori Administrasi Pendidikan, Bandung: Alfabeta, 2011.

Fachruddin Saudagar \& Ali Idrus, Pengembangan Profesionalitas Guru. Jakarta: Gaung Persada (GP Press), 2011.

Fatah, Dkk. Rekontruksi Pesantren Masa Depan. Jakarta Utara: PT. Listafariska Putra, 2005.

Galang Surya Gumilang, (2016).’Metode Penelitian Kualitatif dalam Bidang Bimbingan dan Konseling”.Jurnal Fokus Konseling. Tersedia online di http://ejournal.stkipmpringsewu-lpg.ac.id diakses 27 Februari 2018 pukul 23.00 Wib.

Haedari, H.Amin. Transformasi Pesantren. Jakarta: Media Nusantara, 2007.

Herabudin. Administrasi dan Supervisi Pendidikan.Bandung: Pustaka Setia, 2009.

Hikmat.Manajemen Pendidikan.Bandung: Pustaka Setia, 2009.

Husaini Usman. Manajemen: Teori, Praktik, dan Riset Pendidikan. Jakarta: Bumi Aksara, 2010. 
Irwan Nasution dan Amiruddin Siahaan, Manajemen Pengembangan Profesionalitas Guru. Bandung: Cita Pustaka Media, 2009.

Kartono Kartini. Pemimpin dan Kepemimpinan. Jakarta: Rajawali Press, 2017.

Kompri. Standarisasi Kompetensi Kepala Sekolah: Pendekatan Teori untuk Praktik Profesional Edisi Pertama.Jakarta: Kencana, 2017.

Kompri. Standarisasi Kompetensi Kepala Sekolah: Pendekatan Teori untuk Praktik Profesional Edisi Pertama.Jakarta: Kencana, 2017.

Kunandar.Guru Profesional Implementasi KTSP Dan Sukses Dalam Sertifikasi Guru. Jakarta: Rajawali Pers, 2007.

Lexy J.Moleong. Metodologi Penelitian Kualitatif. Bandung: Remaja Rosdakarya, 2006.

M. Ardansyah, dkk.Administrasi Pendidikan: Suatu Pengantar (Edisi Revisi).Medan: Widya Puspita, 2017.

Malayu S.P Hasibuan. Manajemen: Dasar, Pengertian dan Masalah, Jakarta: Bumi Aksara, 2011.

Mastuki, Dkk. Intelektualisme Pesantren. Jakarta: Diva Pustaka, 2006.

Mhd. Gade Ismail.Penelitian Kualitatif.Banda Aceh: Syiah Kuala, 1993.

Muhammat Rahman dan Sofan Amri. Kode Etik Profesi Guru: Legalitas, Realitas dan Harapan (Wacana Untuk Menunjang Dan Menjadikan Guru Profesional).Jakarta: Prestasi Pustaka, 2014.

Ngalim Purwanto. Administrasi Dan Supervisi Pendidikan. Bandung: Remaja Rosdakarya, 2006.

Nurcholis Madjid, Bilik-Bilik Pesantren Sebuah Potret Perjalanan. Jakarta: Paramadina, 1997.

Rahmat Hidayat dan Henni Syafriana Nasution. Filsafat Pendidikan Islam: Membangun Konsep Dasar Pendidikan Islam.Medan: LPPI, 2016.

Rusydi Ananda dan Amiruddin.Inovasi Pendidikan: Melejitkan Potensi Teknologi dan Inovasi Pendidikan.Medan: Widya Pustaka, 2017.

S. Nasution. Sosiologi Pendidikan. Jakarta: Bumi Aksara, 2011.

Salim dan Syahrum. Metodologi Penelitian Kualitatif. Bandung: Cipta Pustaka, 2007. 
Soetjipto.Profesi Keguruan Cet 4, Jakarta: Rineka Cipta, 2009.

Sofan Amri dan Mahammad Rahman. Kode Etik Profesi Guru. Jakarta: Prestasi Pustakaraya, 2014.

Sudjono Prasodjo.Profil Pesantren. Jakarta: LP3S, 1982.

Syafaruddin dan Asrul. Kepemimpinan Pendidikan Kontemporer.Bandung: Citapustaka Media, 2015.

Syafaruddin. Ilmu Pendidikan Islam (Melejitkan Potensi Budaya Umat). Jakarta: Hijri Pustaka Utama, 2017.

Syafaruddin. Manajemen Organisasi Pendidikan Perspektif Sains dan Islam.Medan: Perdana Publishing, 2017.

Syafaruddin. Sosiologi Pendidikan.Medan: Perdana Publishing, 2016.

Tim Dosen Administrasi Pendidikan Universitas Pendidikan Indonesia. Manajemen Pendidikan, Bandung: Alfabeta, 2011.

Undang-Undang Nomor 14 Tahun 2005 Pasal 1 Ayat 1 Tentang Guru dan Dosen

Undang-Undang Sistm Pendidikan Nasional Nomor 20 Tahun 2003 Bab 1 Pasal 1 Tentang Tenaga Pendidik dan Tenaga Kependidikan

Yusuf Hadijaya. Menyusun Strategi Berbuah Kinerja Pendidik Efektif (Cetakan Kedua).Medan: Perdana Publishing, 2017.

Zamakhsyari Dhofier.Tradisi Pesantren Studi tentang Pandangan Hidup Kyai. LP3S: Jakarta, 1983. 